\title{
LEGITIMIDADE DA DEFENSORIA PÚBLICA PARA PROMOVER AÇÃO CIVIL PÚBLICA POR IMPROBIDADE ADMINISTRATIVA DECORRENTE DA OMISSÃO DE POLÍTICAS DE SAÚDE
}

\author{
LEGITIMACY OF THE PUBLIC DEFENDER TO PROMOTE PUBLIC CIVIL \\ ACTION FOR ADMINISTRATIVE IMPROBITY ARISING OUT OF THE \\ OMMISSION OF HEALTH POLICIES
}

\section{LEGITIMIDAD DE LA DEFENSORIA PÚBLICA PARA PROMOVER ACCIÓN CIVIL PÚBLICA POR IMPROBIDAD ADMINISTRATIVA DE LA OMISIÓN DE POLÍTICAS

http://orcid.org/0000-0001-8519-2280 / http://lattes.cnpq.br/9347562683746206 / marcelolamy@unisanta.br Doutor em Direito Constitucional (PUCSP). Mestre em Direito Administrativo (USP). Bacharel em Direito (UFPR).

Professor Permanente do Programa de Pós-Graduação Stricto Sensu, Mestrado em Direito da Saúde da Universidade Santa Cećlia. Líder do Grupo de Pesquisa CNPq Direitos Humanos e Desenvolvimento Sustentável. Coordenador do Laboratório de Políticas Públicas. São Paulo, SP, Brasil

FLÁVIO ANTONIO dE OLIVEIRA

http://orcid.org/0000-0001-5110-6321 / http://lattes.cnpq.br/7194013591635770 / flavio.dpms@ibest.com.br Mestrando em Direito da Saúde na Universidade Santa Cecília. Especialista em Direito Processual Constitucional (UFMS). Bacharel em Direito (Fac. Dir. de São Carlos). Membro da Defensoria Pública de Mato Grosso do Sul. Três Lagoas, MS - Brasil

\section{RESUMO}

O presente artigo tem por objetivo defender a legitimidade ativa conglobante da Defensoria Pública para a tutela coletiva repressiva por improbidade administrativa decorrente de omissão na implementação da saúde pública, eis que a tutela coletiva a cargo da Defensoria Pública é ampla, sem limitações temáticas que possam obstar a atuação plena dessa instituição em prol da efetivação de direitos e garantias fundamentais em juízo. Para tanto, o estudo em testilha constrói-se com embasamento na exegese global do ordenamento jurídico pátrio à luz dos princípios da máxima efetividade das normas constitucionais e do acesso à justiça: verdadeiros vetores de racionalização interpretativa na elucidação do tema. Amparado em estudo bibliográfico e documental, a pesquisa foi desenvolvida sob a abordagem jus positivista normativista, para identificar os argumentos preponderantes ou excludentes incidentes sobre o raciocínio jurídico atinente à questão.

Palavras-chave: Tutela Coletiva; Saúde; Improbidade Administrativa; Legitimidade; Defensoria Pública.

\section{ABSTRACT}

The purpose of this article is to defend the conglobant active legitimacy of Public Defenders for collective and repressive tutelage for administrative improbity resulting from omission in the implementation of public health actions. This is because the collective tutelage attributed to the Public Defenders is broad, without thematic limitations that may prevent the full performance of this institution in favor of fundamentals rights and guarantees in judgment. For this purpose, the study is based on the global exegesis of the Brazilian legal system inspired by the principles of maximum effectiveness of constitutionals norms and of the access to justice: true vectors of interpretative rationazation in the elucidation of the theme. Based on a bibliographical and documentary study, the 
LEGITIMIDADE DA DEFENSORIA PÚBLICA PARA PROMOVER AÇÃO CIVIL PÚBLICA POR IMPROBIDADE ADMINISTRATIVA DECORRENTE DA OMISSÃO DE POLÍTICAS DE SAÚDE

research was developed under the normativist jus positivist approach, to identify the preponderant or excluding arguments about the legal reasoning that refers to the issue.

Keywords: Collective Tutelage; Health; Administrative Improbity; Legitimacy; Public Defenders.

\section{RESUMEN}

El presente artículo tiene por objeto defender la legitimidad activa conglobante de la Defensoría Pública para la tutela colectiva represiva por improbidad administrativa derivada de la omisión en la implementación de la salud pública, pues la tutela colectiva atribuida a la Defensoría Pública es amplia, sin limitaciones temáticas que puedan obstaculizar la actuación plena de esa institución en favor de la efectividad de derechos y garantías fundamentales en juicio. Para estos fines, el estudio se construye con base en la exegesis global del ordenamiento jurídico brasileño a la luz de los principios de la máxima efectividad de las normas constitucionales y del acceso a la justicia: verdaderos vectores de la racionalización interpretativa en la elucidación del tema. Amparado en estudio bibliográfico y documental, la investigación fue desarrollada bajo el abordaje jus positivista normativista, para identificar los argumentos preponderantes o excluyentes incidentes sobre el raciocinio jurídico que se refiere a la cuestión.

Palabras clave: Tutela Colectiva; Salud; Improbidad Administrativa; Legitimidad; Defensoría Pública.

\section{SUMÁRIO}

INTRODUÇÃO; 1 EVOLUÇÃO NORMATIVA DA LEGITIMIDADE E DO OBJETO DA AÇÃO CIVIL PÚBLICA;2 SUBSTRATO TEÓRICO-CONSTITUCIONAL DA LEGITIMAC̄̃O; 3 SUBSTRATO TEÓRICO-PROCESSUAL DA LEGITIMAÇÃO; 4 A OMISSÃO NA IMPLEMENTAÇÃO DA SAÚDE PÚBLICA COMO ATO PASSÍVEL DE RESPONSABILIZAÇÃO POR IMPROBIDADE ADMINISTRATIVA; 5 A SITUAÇÃO EMPÍRICA DA LEGITIMAÇÃO; 6 A NECESSIDADE COMO JUSTIFICAÇÃO DA LEGITIMAÇÃO CONGLOBANTE; CONCLUSÕES; REFERÊNCIAS.

\section{INTRODUÇÃO}

Em que pese o avanço da Lei de Ação Civil Pública ter incluído a Defensoria Pública no rol dos legitimados para a sua promoção (artigo $5^{\circ}$, inciso II), tem havido alguma resistência quanto à amplitude dessa previsão, sob argumento de não haver previsão legal expressa para aludida legitimidade relativamente a determinados assuntos.

De maneira geral, os tribunais têm admitido a legitimidade da Defensoria Pública para o ajuizamento das Ações Civis Públicas acerca dos mais variados temas, superando parcialmente essa resistência. Resta, no entanto, uma forte resistência para se admitir que a Defensoria possa utilizar-se da Ação Civil Pública para manejar o tema da Improbidade Administrativa, visto que a lei de regência desse último tema atribui a legitimidade expressamente apenas ao Ministério Público. 
ISSN 1981-3694

(DOI): $10.5902 / 1981369429661$

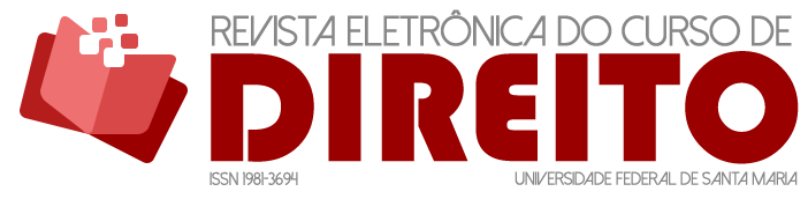

LEGITIMIDADE DA DEFENSORIA PÚBLICA PARA PROMOVER AÇÃO CIVIL PÚBLICA POR IMPROBIDADE ADMINISTRATIVA DECORRENTE DA OMISSÃO DE POLÍTICAS DE SAÚDE

O escopo deste artigo é demonstrar que a legitimidade da Defensoria Pública para a tutela coletiva da improbidade administrativa ante a omissão da implementação de ações de saúde pública é decorrência lógica do substrato normativo de nosso ordenamento.

Para tanto, utiliza-se da abordagem metódica jus positivista (de perfil racionalista, dedutivo e normativista): apresenta os postulados normativos (tópico 1), constitucionais (tópico 2) e processuais (tópico 3), avaliando - ressalte-se, sob o viés jus positivista normativista -, os argumentos doutrinários e jurisdicionais que se projetam sobre a temática normativa (tópicos 4 a 6), extraindo, ao final, as inferências lógicas possíveis.

Para a coleta de informações, a pesquisa revestiu-se dos perfis bibliográfico (doutrina) e documental (normas e decisões judiciais).

Diante das informações encontradas, fez-se análise dos argumentos que podem ser considerados preponderantes ou excludentes, à luz da teoria do raciocínio jurídico de Joseph Raz.

0 presente estudo se desdobra na discussão dos contornos jurídico-normativos constitucionais e legais da legitimação da Defensoria Pública para a Tutela Coletiva por meio das Ações Civis Públicas, enfocando a possibilidade de tutela coletiva do interesse público através da persecução da improbidade administrativa por meio da Ação Civil Pública a cargo da Defensoria Pública.

Portanto, as implicações dos debates tracejados no bojo deste trabalho evidenciam a Defensoria Pública como Instituição legitimada a promover a tutela da probidade administrativa ampliando o acesso à justiça como meio de efetivação dos direitos constitucionalmente garantidos, revelando e oferecendo respostas adequadas aos conflitos hipotetizados.

\section{EVOLUÇÃO NORMATIVA DA LEGITIMIDADE E DO OBJETO DA AÇÃO CIVIL PÚBLICA}

A LC 40/1981 inicia a história normativa da ação civil pública em terras brasileiras, estabelecendo ser função institucional do Ministério Público Estadual promover essa ação (art. $\left.3^{\circ}, \mathrm{III}\right)$.

A Lei $n^{\circ} 7.347 / 1985$ reguladora da ação civil pública, previa originalmente que as ações civis públicas poderiam ser interpostas pelo Ministério Público, pela União, pelos Estados e Municípios, por autarquia, empresa pública, fundação, sociedade de economia mista ou por associação. Por outro lado, previa essa ação como via de responsabilizar por danos causados ao 
ISSN 1981-3694

(DOI): $10.5902 / 1981369429661$

LEGITIMIDADE DA DEFENSORIA PÚBLICA PARA PROMOVER AÇÃO CIVIL PÚBLICA POR IMPROBIDADE ADMINISTRATIVA DECORRENTE DA OMISSÃO DE POLÍTICAS DE SAÚDE

meio-ambiente; ao consumidor; a bens e direitos de valor artístico, estético, histórico, turístico e paisagístico (a previsão original de responsabilizar por danos a qualquer outro interesse difuso foi vetada, na ocasião, pelo Executivo).

A Constituição Federal de 1988 previu a ação civil pública como função institucional do Ministério Público visando a proteção do patrimônio público e social, do meio ambiente e de outros interesses difusos e coletivos (art. 129, III), superando a vedação anterior.

A Lei 7.853/1989 incluiu nas finalidades da ação civil pública a proteção de interesses coletivos, difusos, individuais homogêneos e individuais indisponíveis da pessoa com deficiência.

A Lei 7.913/1989 instituiu a ação civil pública de responsabilidade por danos causados aos investidores no mercado de valores mobiliários, invocando como legitimado para essa ação o Ministério Público.

A Lei 8.069/1990 (Estatuto da Criança e do Adolescente) incluiu nas finalidades da ação civil pública a proteção dos interesses individuais, difusos ou coletivos relativos à infância e à adolescência, inclusive os definidos no art. 220, § $3^{\circ}$ inciso II, da Constituição Federal.

A Lei 8.078/1990 (Código de Defesa do Consumidor) modificou a Lei 7.347/1985 para inserir expressamente entre as finalidades da ação civil pública a responsabilização já prevista na Constituição por danos a qualquer outro interesse difuso ou coletivo.

A Lei 8.625/1993 (Lei Orgânica do Ministério Público) explicitou que ao Ministério Público cabe promover a ação civil pública para a proteção, prevenção e reparação dos danos causados ao meio ambiente, ao consumidor, aos bens e direitos de valor artístico, estético, histórico, turístico e paisagístico, e a outros interesses difusos, coletivos e individuais indisponíveis e homogêneos; para a anulação ou declaração de nulidade de atos lesivos ao patrimônio público ou à moralidade administrativa do Estado ou de Município, de suas administrações indiretas ou fundacionais ou de entidades privadas de que participem.

A Lei 8.884/1994 incluiu nas finalidades da ação civil pública a responsabilização por danos causados por infração da ordem econômica.

A MP 2.180-35/2001 incluiu nas finalidades da ação civil pública a responsabilização por danos causados à ordem urbanística.

A Lei 10.141/2003 (Estatuto do Idoso) incluiu nas finalidades da ação civil pública a proteção dos direitos e interesses difusos ou coletivos, individuais indisponíveis e individuais homogêneos do idoso.

A Lei 11.448/2007 explicitou a legitimidade da Defensoria Pública para promover essa ação, inserindo-a no rol de legitimados da ação civil pública elencados no artigo $5^{\circ}$ da Lei 
ISSN 1981-3694

(DOI): $10.5902 / 1981369429661$

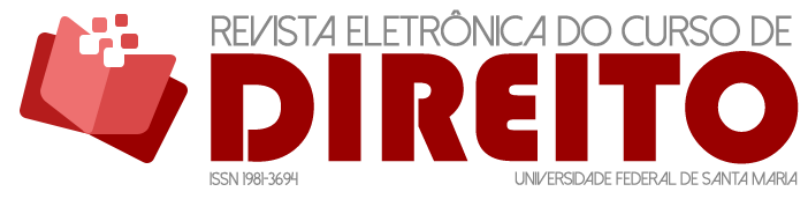

LEGITIMIDADE DA DEFENSORIA PÚBLICA PARA PROMOVER AÇÃO CIVIL PÚBLICA POR IMPROBIDADE ADMINISTRATIVA DECORRENTE DA OMISSÃO DE POLÍTICAS DE SAÚDE

7.347/1985. O que indubitavelmente concretiza o próprio $\S 1^{\circ}$ do artigo 129 da Constituição Federal: “A legitimação do Ministério Público para as ações civis previstas neste artigo não impede a de terceiros, nas mesmas hipóteses, segundo o disposto nesta Constituição e na lei”.

Considerando a força vinculante normativa, cita-se a ADI 3.943 (julgada em 07/05/2015), na qual o STF reconheceu a constitucionalidade dessa inserção. A impugnação dessa legitimação fora ancorada no raciocínio de que a Defensoria Pública possui legitimidade para representar aos necessitados; e, em função disso, somente poderia impetrar ações civis públicas onde fosse possível individualizar a carência financeira. Inviável seria, nessa lógica, ações civis públicas em defesa de direitos difusos. Ocorre que o Supremo - amparado em escorreita preocupação com a máxima efetividade das garantias constitucionais e com a assistência almejada pela Constituição aos necessitados - considerando que a simples presunção de que, no rol dos afetados pelos resultados da ação coletiva, constem pessoas necessitadas é suficiente para justificar a legitimidade da Defensoria Pública - entendeu que se a Constituição não estabeleceu qualquer limitação ou restrição para a Defensoria tutelar aos necessitados, não será a interpretação que isto fará; ademais que a legitimidade da Defensoria não prejudica a do Ministério Público. Restou reconhecida, portanto, a legitimidade da Defensoria para a defesa de interesses transindividuais.

Em razão da observância obrigatória aos membros do Poder Judiciário por força do artigo 927, inciso III do CPC, cita-se o RE 733.433 (julgado em 04/11/2015, com repercussão geral), no qual ficou assentada a tese de que a Defensoria Pública tem legitimidade para a propositura de ação civil pública que vise a promover a tutela judicial de direitos difusos e coletivos de que sejam titulares, em tese, pessoas necessitadas (tema 607). Se, em tese, os resultados da ação beneficiarão aos necessitados, carentes, hipossuficientes, menos afortunados ou pessoas pertencentes aos estratos economicamente mais débeis ou menos organizados da coletividade, é legitima a atuação da Defensoria.

A LC 132/2009, alterando a lei orgânica da Defensoria Pública da União, do Distrito Federal e dos Territórios (LC $n^{\circ}$ 80/1994), inseriu entre as funções institucionais da Defensoria: "promover ação civil pública e todas as espécies de ações capazes de propiciar a adequada tutela dos direitos difusos, coletivos ou individuais homogêneos quando o resultado da demanda puder beneficiar grupo de pessoas hipossuficientes" (art. $\left.4^{\circ}, \mathrm{VII}\right)$.

A Lei 12.529/2011 explicitou que a responsabilidade por danos da ação civil pública abrange os danos morais e patrimoniais. 
ISSN 1981-3694

(DOI): $10.5902 / 1981369429661$

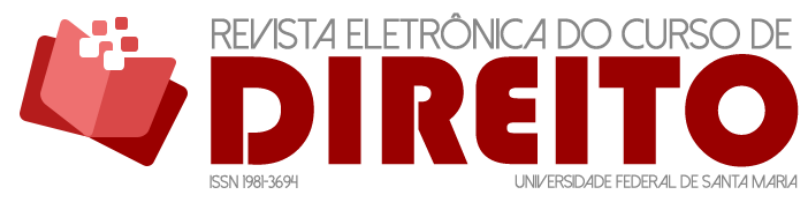

LEGITIMIDADE DA DEFENSORIA PÚBLICA PARA PROMOVER AÇÃO CIVIL PÚBLICA POR IMPROBIDADE ADMINISTRATIVA DECORRENTE DA OMISSÃO DE POLÍTICAS DE SAÚDE

A EC 80/2014 alterou a redação do artigo 134 da Constituição Federal, estabelecendo que à Defensoria incumbe - além da orientação jurídica e a defesa, em todos os graus, dos necessitados (originalmente previstos) - a promoção dos direitos humanos; explicitando que a defesa pode se dar pelas vias judicial e extrajudicial, que se projeta sobre direitos individuais e coletivos de forma integral.

A Lei 12.966/2014 incluiu nas finalidades da ação civil pública a responsabilização por danos à honra e à dignidade de grupos raciais, étnicos ou religiosos.

A Lei 13.004/2014 modificou a Lei 7.347/1985 para inserir expressamente entre as finalidades da ação civil pública a responsabilização já prevista na Constituição por danos ao patrimônio público e social.

\section{SUBSTRATO TEÓRICO-CONSTITUCIONAL DA LEGITIMAÇÃO}

Desde a Declaração de Direitos do Homem e do Cidadão, de 1789, os olhares de todos os juristas têm se direcionado à necessidade de garantir os direitos: "Art. 160. A sociedade em que não esteja assegurada a garantia dos direitos nem estabelecida a separação dos poderes não tem Constituição".

O termo "garantia constitucional”, sucedâneo dessa preocupação, abrange qualquer instrumento, instituição, determinação ou procedimento que a Constituição utilize para tutelar ou concretizar os comandos jurídicos ou os direitos por ela declarados. Por sua vez, o termo “remédio constitucional" reflete qualquer instrumento (ou garantia constitucional) apto a provocar uma autoridade pública em defesa do padecimento real ou eventual de um direito constitucional declarado (prevenindo ou restaurando esse direito). Enquanto que o termo "ação constitucional" refere-se ao conjunto de remédios constitucionais que provoca a atuação de uma autoridade concreta do Poder Judiciário. Por outro lado, o termo "writs constitucionais", de origem inglesa, agasalha o sentido de ordem, de mandamento expedido pelo Judiciário a quem deve cumprir a lei. As ações constitucionais amparam também esse significado, razão pela qual muitas vezes as ações constitucionais são chamadas dessa forma, como writs constitucionais.

O termo ação, por sua vez, possui diversos e mutáveis aportes significativos, segundo o espaço e o tempo: direito de alguém perseguir em juízo o que the é devido ou o que é seu (teoria imanente); possibilidade de exigir a realização de um direito ou de uma vontade através do Judiciário (teoria autônoma concreta); direito público subjetivo ao pronunciamento judicial (teoria autônoma abstrata) etc. De qualquer forma, é possível identificar, no vasto percurso 
ISSN 1981-3694

(DOI): $10.5902 / 1981369429661$

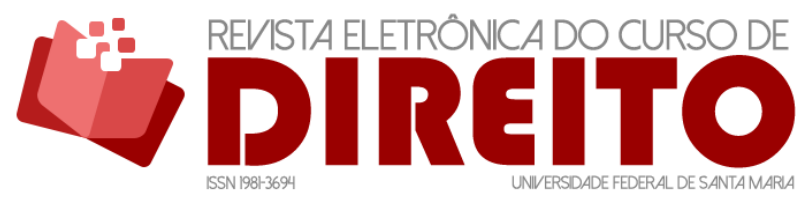

LEGITIMIDADE DA DEFENSORIA PÚBLICA PARA PROMOVER AÇÃO CIVIL PÚBLICA POR IMPROBIDADE ADMINISTRATIVA DECORRENTE DA OMISSÃO DE POLÍTICAS DE SAÚDE

histórico desse tema, um núcleo significativo estável: o direito a um julgamento (se presente as condições da ação - requisitos para o julgamento do pedido e não propriamente elementos constitutivos da ação) ou, pelo menos, o direito à manifestação judicial.

Partindo dessa concepção, moldada no bojo do Estado constitucional de direito: ação é todo instrumento previsto normativamente apto a provocar e a exigir a manifestação judicial; constitucional é todo instrumento desta estirpe previsto clara e explicitamente no Texto Constitucional.

Sob esse enfoque conceitual é possível identificar as três categorias de instrumentos constitucionais antes referidos relacionados ao Judiciário.

$\mathrm{Na}$ primeira categoria, a Constituição brasileira de 1988 apresenta um conjunto de garantias constitucionais dirigido exclusivamente para o Judiciário assegurar a compatibilidade ou a adequação de atos normativos infraconstitucionais ou mesmo de atos executivos com relação aos comandos constitucionais (próprias do sistema de controle judicial da constitucionalidade), que apenas indiretamente tutelam direitos: (1) Representação Interventiva (art. 36, III, conjugado ao Art. 34, VII, alíneas 'a', 'b', 'd' e 'e'); (2) Ação Direta de Inconstitucionalidade de Lei ou Ato Normativo Federal ou Estadual por Ação (art. 102, I, 'a') ou por Omissão (art. 103, §2); (3) Ação Declaratória de Constitucionalidade de Lei ou Ato Normativo Federal (art. 102, I, ‘a’); (4) Reclamação Constitucional (art. 102, I, 'l’ e art. 103-A, §3); (5) Recurso Extraordinário (art. 102, III); (6) Arguição de Descumprimento de Preceito Fundamental (art. 102, §1); (7) Súmula Vinculante (art. 103-A).

Na segunda categoria, é possível identificar na Constituição brasileira um bloco de ações constitucionais que tutelam diretamente direitos: (1) Representação Interventiva (art. 36, III, conjugado ao Art. 34, VII, alínea c); (2) Habeas corpus (art. 5, LXVIII); (3) Mandado de Segurança Individual (art. 5०, LXIX ); (4) Mandado de Segurança Coletivo (art. 5, LXX); (5) Mandado de Injunção (art. 5, LXXI); (6) Habeas data (art. 5, LXXII); (7) Ação Popular (art. 5², LXXIII); (8) Ação de Desapropriação (art. 5º XXIV, combinado com os arts. 182 e 184 ); (9) Ação

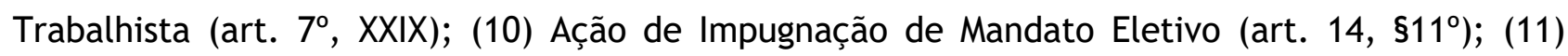
Ação Civil Pública (art. 129, III).

A Constituição prevê ainda dois remédios constitucionais, que, tutelando direitos, podem ser dirigidos tanto ao Judiciário quanto aos demais poderes: (1) o direito de petição (art. $5^{\circ}$, XXXIV, a) e (2) o direito de certidão (art. $5^{\circ}$, XXXIV, b).

Se esses instrumentos são constitucionais, o estudo deles, portanto, deve principiar por esse fator, por esse enfoque, pelo fato de terem sido destacados pela própria Constituição de 
ISSN 1981-3694

(DOI): $10.5902 / 1981369429661$

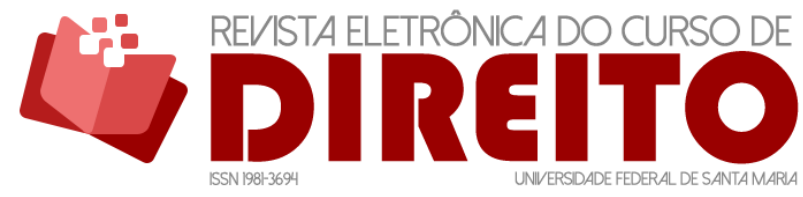

LEGITIMIDADE DA DEFENSORIA PÚBLICA PARA PROMOVER AÇÃO CIVIL PÚBLICA POR IMPROBIDADE ADMINISTRATIVA DECORRENTE DA OMISSÃO DE POLÍTICAS DE SAÚDE

todas as demais medidas do ordenamento. Ora, a constitucionalização de qualquer instituto jurídico (mesmo que vetusto), não constitui fenômeno banal ou mero simbolismo. Pelo contrário, é algo que deve ser analisado com muita diligência. A inserção de qualquer instituto na Constituição traz incontáveis aportes, pois lhes confere o vigor próprio das normas constitucionais, a pujança própria do comando hierárquico máximo. Porque integra a Constituição tudo o que fora constitucionalizado, conferindo proximidade com os anseios básicos da nação com o conjunto de pautas éticas da sociedade em que se insere (nos anos 50, o Tribunal Constitucional Alemão inferiu conclusão certeira: o conjunto de direitos e garantias fundamentais de um povo não é apenas um conjunto de direitos subjetivos, mas uma pauta ética para toda a sociedade).

Se a Constituição não se conteve em simplesmente declarar direitos, mas constituiu instrumentos especiais para a proteção de determinados direitos, urge explicitar a conexão desses institutos com uma teoria geral aplicável a todas essas garantias, remédios e ações.

De imediato, qualquer instituto constitucionalizado, pelo simples fato de integrar a Constituição, passa a compor o rol dos fundamentos do ordenamento jurídico. Alterada sua importância e sua hierarquia, deixa de se sujeitar ao sabor do legislador ordinário e ganha o manto indevassável de seu núcleo constitucional. Em outras palavras, seu conteúdo significativo constitucional torna-se inalterável pela legislação infraconstitucional.

Celso Seixas Ribeiro Bastos e Carlos Ayres de Brito ${ }^{(1)}$ indicam-nos o caminho.

Todas as normas constitucionais visam produzir efeitos. Algumas se predispõem, por si mesmas, a produzir tais efeitos (normas de aplicação); outras, reclamam a intermediação de normas inferiores (normas de integração). Se atingem o seu desiderato são tidas como de eficácia plena, se não alcançam, como de eficácia parcial.

Se o enunciado normativo é completo e não necessita de complemento para produzir os efeitos almejados, estamos diante de normas de aplicação. Essas normas constitucionais são em princípio irregulamentáveis ou irreforçáveis, pois foram concebidas de modo absoluto. São normas à espera de cumprimento e não de regulamentação. Embora sejam comandos explicitados de forma definitiva e exauriente, pode ocorrer, no entanto, que venham a obter da legislação inferior maior perspectiva de funcionalidade. Podem ser tidas, portanto, como normas de operacionalidade reforçável. Não recebem novo sentido, apenas desdobramentos externos, operacionais. Normas declarativas ou concessivas de direitos subjetivos, embora possuam

${ }^{1}$ Cf. BASTOS, Celso Seixas Ribeiro; BRITO, Carlos Ayres de. Interpretação e Aplicabilidade das Normas Constitucionais. SP: Saraiva, 1982, passim. 
ISSN 1981-3694

(DOI): $10.5902 / 1981369429661$

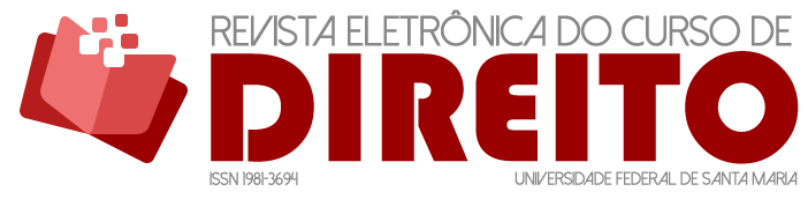

LEGITIMIDADE DA DEFENSORIA PÚBLICA PARA PROMOVER AÇÃO CIVIL PÚBLICA POR IMPROBIDADE ADMINISTRATIVA DECORRENTE DA OMISSÃO DE POLÍTICAS DE SAÚDE

plenitude de significado, também podem ser estendidas a situações não descritas e, por isso, podem ser tidas como normas de conteúdo reforçável. Os novos pressupostos de ocorrência, as novas virtualidades, no entanto, devem ser decorrência da vontade constitucional original. A extensão de conteúdo esbarra nos seguintes limites: não conflitar com outro valor constitucional, em especial com qualquer prerrogativa do poder; não colidir com expressões constitucionais radicais como "unicamente", "exclusivamente" etc. (a vontade constitucional é clara, nesses casos); ou não conflitar com nítida intenção constitucional de exaurir a matéria.

Se os contornos do comando constitucional não estão definitivamente traçados no dispositivo constitucional, necessitando de complemento, estamos diante de normas de integração. Quando compatíveis com delimitação (ou restrição) mais precisa de seu conteúdo, para que alcance seus objetivos, são tidas como normas restringíveis. Possuem força, efetividade plena de imediato, mas podem ser alteradas em seus efeitos com a restrição da legislação inferior. As normas inferiores das normas restringíveis devem ser requisitadas expressamente e assim recebem autorização para melhor explicitar a vontade constitucional (a Constituição deverá apresentar em seus dispositivos expressões como: lei regulará, lei disporá, nos termos da lei etc.). Quando necessitam da definição de elementos lógicos, de pressupostos ou condições objetivas de plena incidência, são tidas como de eficácia limitada e intituladas normas completáveis. A eficácia imediata é parcial, somente quanto a vontade constitucional, não quanto a todos efeitos almejados, que se tornam atos somente com a norma inferior. A Constituição apresenta apenas a ideia abstrata, e sua concretização só é possível pela integração esclarecedora da norma inferior. O propósito deixa-se entrever, mas os efeitos não são operantes. As normas inferiores das normas completáveis, como não alteram a vontade constitucional, podem ser requisitadas expressa ou tacitamente.

Somente nas ações constitucionais de desapropriação e de impugnação de mandato eletivo a Constituição requisita a intervenção legislativa. A regulamentação infraconstitucional dessas ações, portanto, poderia de alguma forma restringir seu conteúdo, desde que assim ficasse evidenciado o melhor atingimento do objetivo constitucional. Não se pode dizer, por outro lado, que as demais ações constitucionais estejam contidas em normas restringíveis, pois não há requisição constitucional de intervenção legislativa. Portanto, o dispositivo constitucional da Ação Civil Pública não pode ser tido como norma restringível.

Não nos parece que os dispositivos das ações constitucionais se enquadrem na categoria normas completáveis, pois a Constituição nesses dispositivos vai muito além da ideia abstrata e seus efeitos foram operantes desde a promulgação da Constituição. 
ISSN 1981-3694

(DOI): $10.5902 / 1981369429661$

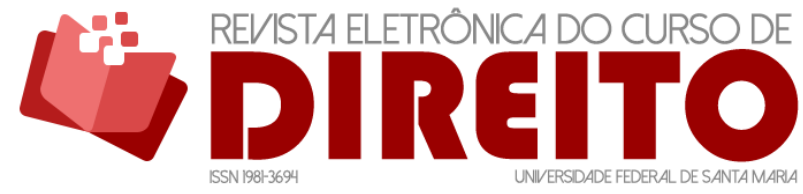

LEGITIMIDADE DA DEFENSORIA PÚBLICA PARA PROMOVER AÇÃO CIVIL PÚBLICA POR IMPROBIDADE ADMINISTRATIVA DECORRENTE DA OMISSÃO DE POLÍTICAS DE SAÚDE

Mesmo que imaginássemos como completáveis, a lei que cumprisse esse encargo, necessariamente deveria respeitar o núcleo essencial das ações constitucionais: a ampla legitimidade para impetrá-las, para que não desvirtuasse o propósito democrático das mesmas (observe-se que somente na representação interventiva, no mandado de segurança coletivo, e no habeas data há limitação constitucional no que diz respeito à legitimidade ativa); os requisitos constitutivos, os objetivos e as consequências almejadas pelas respectivas ações, para que não se desvirtuasse o propósito constitucional das mesmas. Logo, o dispositivo constitucional da Ação Civil Pública não nos parece compatível com a categoria norma completável.

Ademais, a menção à função institucional do Ministério Público promover a ação civil pública não pode ser interpretada como se a Constituição tivesse estabelecido que a ação civil pública somente pudesse ser promovida pelo Ministério Público.

A não exclusividade do Ministério Público como ente legitimado para a propositura de ação civil pública tem fundamento de validade na própria Constituição da República, a qual em seu artigo 129, § $1^{\circ}$ sufraga expressamente que não há óbice para a legitimidade de terceiros para aludida espécie de ação constitucional. Corroborando supracitado fundamento constitucional, é curial verificar que o artigo 134 da Constituição Federal alterado pela EC 80/2014 enaltece a Defensoria Pública como instituição constitucional cuja função precípua é promover os direitos humanos mediante a tutela de direitos coletivos pela defesa judicial ou extrajudicial e de forma integral.

Ora, aludido fundamento constitucional se associa ao postulado constitucional da integralidade da assistência judiciária prevista no artigo $5^{\circ}$ LXXIV, e sobreleva a garantia constitucional subsumida em uma Instituição Pública denominada Defensoria Pública como órgão responsável também pela tutela coletiva da moralidade administrativa e do patrimônio público, eis que - em sua maioria - a sociedade é hipossuficiente não só financeiramente, como tecnicamente, razão pela qual, se dentre as características dos direitos fundamentais estão a não-taxatividade, a complementariedade e universalização, qual razão seria justificável para vedar a legitimidade da Defensoria Pública de ser mais um órgão a serviço da promoção da defesa coletiva dos bens indisponíveis em razão de serem de interesse coletivo?

Se o interesse coletivo nada mais é do que o interesse da sociedade humana, a atuação preventiva ou repressiva da Defensoria Pública culminaria indubitavelmente com a promoção dos direitos humanos de forma integral, mormente em se tratando de atos administrativos desviados da promoção e fomento da saúde pública passíveis de configuração de improbidade. 
ISSN 1981-3694

(DOI): $10.5902 / 1981369429661$

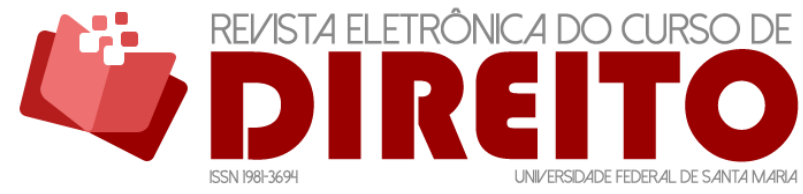

LEGITIMIDADE DA DEFENSORIA PÚBLICA PARA PROMOVER AÇÃO CIVIL PÚBLICA POR IMPROBIDADE ADMINISTRATIVA DECORRENTE DA OMISSÃO DE POLÍTICAS DE SAÚDE

MARCELO LAMY FLÁVIO ANTONIO DE OLIVEIRA

Ademais, atualmente o fundamento de validade normativo pode ser extraído até da própria jurisprudência do Supremo Tribunal Federal, eis que o artigo 102, § $2^{\circ}$ da própria Constituição da República outorga o efeito vinculante às decisões definitivas de mérito em âmbito de Ações Diretas de Inconstitucionalidade e de Ações Declaratórias de Constitucionalidade perante toda a Administração Pública. Em outras palavras, o conteúdo das decisões de mérito do Pretório Excelso possui caráter normativo com força obrigatória e caráter de generalidade. Essa força normativa expansiva oriunda das decisões do Supremo Tribunal Federal teve reflexo legal com o advento do Novo Código de Processo Civil, que, em seu artigo 927, inciso III, compeliu todos os membros e órgãos do Poder Judiciário a observarem o conteúdo de decisões do Supremo Tribunal Federal inclusive em Recursos Extraordinários, tal caráter de respeito cogente das decisões proferidas em Recursos Extraordinários tem lógica a partir da exigência da repercussão geral que afeta toda a sociedade (coletividade), atingindo o interesse coletivo.

Neste ínterim, fica fácil concluir que a base de sustentação constitucional e fundamento de validade da legitimidade da Defensoria Pública em um viés de juridicidade se assenta na ADI 3.943 (julgada em 07/05/2015), em que o STF reconheceu a constitucionalidade da inserção da Defensoria Pública no rol dos legitimados para a propositura de Ações Civis Públicas e no RE 733.433 (julgado em 04/11/2015, com repercussão geral), em que ficou assentada a tese de que a Defensoria Pública tem legitimidade para a propositura de ação civil pública que vise a promover a tutela judicial de direitos difusos e coletivos de que sejam titulares, em tese, pessoas necessitadas (tema 607).

Ora, há de se convir que a perquirição da promoção de saúde pública coletivamente ainda que preventivamente mediante o desestímulo de desvios perante Ação Civil Pública de Improbidade Administrativa a cargo da Defensoria Pública evidencia inquestionável legitimação constitucional, porquanto, se a saúde pública é considerada um bem difuso, por conseguinte as ações civis públicas em defesa de direitos difusos encontrariam legitimidade na Defensoria Pública, pois o controle da eficiência da prestação de serviços de saúde pública, em última análise, significa a promoção dos direitos humanos coletivos, função institucional da Defensoria Pública, conforme determina expressamente a atual LCF 80/94 alterada pela 132/09 em seu artigo $4^{\circ}$, inciso VII.

Nesse passo, se revelou hígida a preocupação do Supremo Tribunal Federal com a máxima efetividade das garantias constitucionais e com a assistência almejada pela Constituição aos necessitados - porquanto, considerando a simples presunção de que no rol dos afetados pelos 
ISSN 1981-3694

(DOI): $10.5902 / 1981369429661$

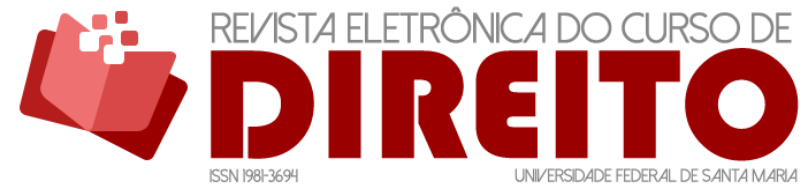

LEGITIMIDADE DA DEFENSORIA PÚBLICA PARA PROMOVER AÇÃO CIVIL PÚBLICA POR IMPROBIDADE ADMINISTRATIVA DECORRENTE DA OMISSÃO DE POLÍTICAS DE SAÚDE

MARCELO LAMY

FLÁVIO ANTONIO DE OLIVEIRA

resultados da ação coletiva constem pessoas necessitadas se torna exaustivamente suficiente a justificação da legitimidade da Defensoria Pública - entendeu que se a Constituição não estabeleceu qualquer limitação ou restrição para a Defensoria tutelar aos necessitados, não será possível fazê-lo mediante interpretação; até porque quanto mais legitimados maior o nível de garantia constitucional ao cidadão, configurando patente, pois, a legitimidade da Defensoria para a defesa de interesses transindividuais.

Boson preleciona não existir possibilidade de uma hermenêutica de restrição da legitimidade da Defensoria Pública por qualquer ângulo que se pretenda analisar, eis que tal Instituição retira o fundamento de validade para sua legitimidade acerca da tutela da probidade administrativa diretamente da Constituição Federal, que é norma jurídica dotada de auto eficácia, senão vejamos:

Dessa primeira consideração apresentada é possível concluir que a legitimidade da Defensoria Pública, na tutela dos direitos do grupos e indivíduos hipossuficientes, não depende de previsão legal, pois tem fundamento constitucional. A segunda consideração tradu-ze no fato de que, uma vez que a Constituição não exclui os necessitados da titularidade do direito à probidade administrativa, o fundamento da legitimidade da Defensoria na defesa da moralidade é constitucional, sendo de tal forma bastante apontar o comando constitucional estatuídos no art. $5^{\circ}$, XXXV, da Constituição Federal para afirmar a legitimidade da Defensoria Pública.[...] Aliás, se a própria Constituição (fundamento maior de legitimidade de qualquer ente estatal) não faz nenhuma ressalva, não é admissível atribuir à legislação infraconstitucional poder para que o faça. Ou seria admissível, por exemplo, mutatis mutandis, alguma lei que, alegando o alto custo estatal, impedisse a atuação defensorial em matéria de direito previdenciário? Ou ainda, mais genericamente, impedisse a atuação da Defensoria contra entidades públicas? A resposta a tais questionamentos é negativa pela mesma razão: o fundamento para a atuação defensorial, nesta seara, é de natureza constitucional, não sendo admissível atribuir à lei poder de diminuir a proteção constitucional.[...]Mais do que constatar que a incumbência constitucional de proteção dos direitos transindividuais do cidadão pela Defensoria não encontra previsão de ressalva no que se refere à temática da moralidade administrativa, é preciso ter em mente que a Ação de Improbidade Administrativa (não obstante os seus possíveis efeitos punitivos) é uma garantia instrumental para a efetividade dos direitos fundamentais.É salutar a consciência de que a garantia constitucional que possibilita o controle da moralidade na administração pública não tem como pauta primária a ideia da repressão estatal. Pelo contrário, o controle da moralidade na administração pública deve ser, antes de tudo, instrumento de efetivação dos direitos do cidadão, de modo que a 
ISSN 1981-3694

(DOI): $10.5902 / 1981369429661$

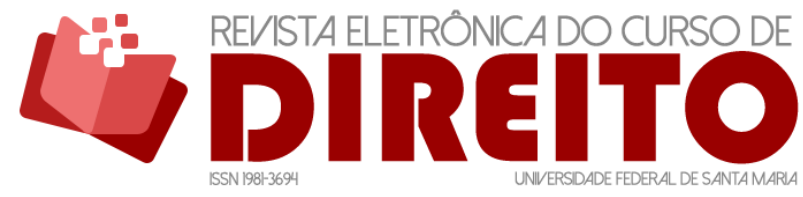

LEGITIMIDADE DA DEFENSORIA PÚBLICA PARA PROMOVER AÇÃO CIVIL PÚBLICA POR IMPROBIDADE ADMINISTRATIVA DECORRENTE DA OMISSÃO DE POLÍTICAS DE SAÚDE

ausência de "aptidão repressiva" da Defensoria Pública em nada depõe contra a sua legitimidade. ${ }^{(2)}$

A probidade administrativa supõe-se ser de interesse coletivo, eis que o princípio constitucional da probidade certamente está diretamente relacionado com o princípio de igual envergadura chamado eficiência. Assim, se a sociedade depende de serviços públicos eficientes, seus direitos humanos restam à mercê do respeito a esses princípios da probidade e eficiência, motivo pelo qual na função institucional de promoção dos direitos humanos coletivamente, detém a Defensoria Pública indissociável legitimidade para perpetrar ações tutelando tais interesses coletivos.

Logo, a lógica geral das ações constitucionais é outra, ou seja, se apoia no raciocínio da ampla legitimação.

Da mesma forma, qualquer restrição infraconstitucional às finalidades das ações constitucionais, torna-se inconstitucional. Nesse sentido, qualquer limitação da utilização da ação civil pública para proteger o patrimônio público contra a improbidade administrativa, como a de estabelecer um único legitimado para esse tipo de ação, desvirtuaria os objetivos constitucionais dessa ação, circunstância que enaltece o diálogo das fontes normativas constitucionais no propósito da ampliação e efetivação dos direitos fundamentais, em razão de suas próprias características.

Como as ações constitucionais, em nosso sentir, foram bem estruturadas pelo constituinte, apresentam-se como normas de aplicação (exceto as já apontadas ações de desapropriação e de impugnação de mandato eletivo), é possível, em função disso, sujeitaremse ao regime das normas de operacionalidade reforçável ou ao regime das normas de conteúdo reforçável.

Pode a legislação infraconstitucional inovar em instrumentos de funcionalidade das ações constitucionais (operacionalidade reforçável). Exemplificamos: estabelecendo medidas de tutela mais eficazes para os propósitos constitucionais; instituindo a legitimidade ativa de instituições antes não previstas - estejam elas implicitamente agasalhadas pela legitimação geral, ou decorram de uma ampliação do rol originalmente previsto; estabelecendo incidentes de abertura democrática para as ações de feição coletiva (como as audiências públicas e a amplificação das

2 BOSON, Erik Palácio. A Defensoria Pública e a Tutela Jurisdicional da Moralidade Administrativa. 2014.103 f. Dissertação (Mestrado em Direito). Universidade de São Paulo. Faculdade de Direito. Disponível em: http://www.teses.usp.br/teses/disponiveis/2/2134/tde-06112015-142121/pt-br.php. Acessado em 25/01/2018, p. 80. 
ISSN 1981-3694

(DOI): $10.5902 / 1981369429661$

LEGITIMIDADE DA DEFENSORIA PÚBLICA PARA PROMOVER AÇÃO CIVIL PÚBLICA POR IMPROBIDADE ADMINISTRATIVA DECORRENTE DA OMISSÃO DE POLÍTICAS DE SAÚDE

possibilidades de integrar os amici curiae). Isto fora consolidado, no que diz respeito à ação civil pública, pelas leis 11.448/2007 (inseriu a Defensoria no rol do artigo $5^{\circ}$ da Lei 7.347/1985 LACP), pela LCF 132/2009 (alterou a LCF n 80/1994, inserindo (art. 4 , VII) a função institucional da Defensoria Pública de: “promover ação civil pública e todas as espécies de ações capazes de propiciar a adequada tutela dos direitos difusos, coletivos ou individuais homogêneos quando o resultado da demanda puder beneficiar grupo de pessoas hipossuficientes" e pela EC 80/2014 que alterou a redação do artigo 134 da Constituição Federal, estabelecendo que à Defensoria incumbe - além da orientação jurídica e a defesa, em todos os graus, dos necessitados (originalmente previstos) - a promoção dos direitos humanos; explicitando que a defesa pode se dar pelas vias judicial e extrajudicial, que se projeta sobre direitos individuais e coletivos de forma integral.

Acerca do reforço de operacionalidade, parece-nos que o inverso disso fora o efetivado pela Lei 8.437/1992 no que diz respeito às cautelares contra o Poder Público. Nesse caso, ao invés de reforçar a operacionalidade, essa fora reduzida, o que revela ofensa a lógica das ações constitucionais.

Pode a legislação infraconstitucional estender as ações constitucionais para novas situações não pensadas originalmente, mas que se assemelham ao que se quer proteger (conteúdo reforçável), desde que não colidam com dispositivos constitucionais que sejam categóricos quanto à amplitude do instrumento, o que ocorre no conjunto das ações constitucionais somente com a representação interventiva (motivo pelo qual as hipóteses de intervenção foram alteradas pelas emendas constitucionais 14/ 1996 e 29/2000 e 45/2004).

As possíveis limitações às ações constitucionais, por serem normas de aplicação, advêm única e exclusivamente da própria Constituição. Não pode a lei regulamentadora ou reforçadora transformar-se em lei restritora.

Se lei regulamentadora impede que determinados legitimados exerçam seu mister, se pretensa regulamentação apresenta requisitos constitutivos (condições para o exercício da ação) não previstos pelo Texto Constitucional, se lei reguladora altera o resultado almejado pela Constituição; em todos esses casos, estaremos diante de uma lei inconstitucional.

\section{SUBSTRATO TEÓRICO-PROCESSUAL DA LEGITIMAÇÃO}

Sem qualquer censura ao Ministério Público brasileiro, o qual, porém, através de sua Associação Nacional, questionou no Supremo Tribunal Federal a legitimidade da Defensoria 
Pública para a propositura de Ação Civil Pública, é digno de nota expor que na Constituição da República de 1967 o Ministério Público não tinha elenco de atribuições institucionais constitucionalizadas, pois, eram estas relegadas à sua legislação orgânica, sendo que tal Instituição somente em 1981, através da então Lei Complementar Federal n 40/81 (Lei Orgânica Nacional do Ministério Público), previu em seu artigo $3^{\circ}$, inciso III, a sua legitimação para a Ação Civil Pública como função institucional, havendo sucessão desta previsão na Lei 7.347 de 1985 para a defesa da coletividade acerca de tais valores, isto é, antes do advento da Constituição da República de 1.988. Vale dizer que o Ministério Público já tinha atribuição para propor Ações Civis Públicas antes da promulgação da atual Constituição Federal e independentemente do que nela estava expressamente previsto.

Mutatis mutandis, qual o fundamento de se pretender objetar que a Defensoria Pública embora sem expressa positivação de rol de atribuições institucionais na Constituição de 1.988 tenha legitimidade para a Ação Civil Pública, se ela, em 2007, foi incluída pela Lei 11.448/07 no rol dos legitimados na própria Lei da Ação Civil Pública, bem como se a Lei Complementar Federal n 80/94 (alterada pela LCF 132/09) - que é a Lei Orgânica Nacional da Defensoria também previu a legitimação da Defensoria Pública para promover a defesa da tutela coletiva através da Ação Civil Pública?

A respeito, vale colacionar o ensinamento de Saldanha:

Tanto a Lei da Ação Civil Pública, como a Lei de Improbidade Administrativa, que são, respectivamente, de 1985 e de 1992, não previram a Defensoria Pública, originariamente, em seus textos. No entanto, seria impossível pensar em omissão proposital do legislador, pois a Defensoria Pública só passou a existir formalmente na nossa Lei Magna atual (1988) e, em norma legal nacional, apenas em 1994 com a Lei Complementar n. 80. Os movimentos de instalação, aprimoramento e valorização das Defensorias Públicas pelo Brasil afora, somente tomaram corpo e força no final da década de 1990 e princípio da década de 2000. Isto quer dizer que, antes dessas datas, não era crível ver a Defensoria Pública inserida nos diplomas legais, pois ainda inexistente ou incipiente. ${ }^{(3)}$

Curial se verificar que a nova redação dada ao artigo 134 da Constituição Federal pela EC 80/2014 prevê como incumbência fundamental da Defensoria Pública a promoção dos direitos

\footnotetext{
${ }^{3}$ SALDANHA, Alexandre de Moraes. Da legitimidade ativa da defensoria pública para a propositura de demandas pela prática de atos de improbidade administrativa. Revista da Defensoria Pública da União. Brasília, n. 7 (2014). Disponível em: http://revistadadpu.dpu.def.br/index.php/dpu/article/view/40/37, p. 69.
} 
ISSN 1981-3694

(DOI): $10.5902 / 1981369429661$

LEGITIMIDADE DA DEFENSORIA PÚBLICA PARA PROMOVER AÇÃO CIVIL PÚBLICA POR IMPROBIDADE ADMINISTRATIVA DECORRENTE DA OMISSÃO DE POLÍTICAS DE SAÚDE

humanos e a defesa, em todos os graus, judicial e extrajudicialmente, também dos direitos coletivos, de forma integral.

A legitimação concorrente para a Ação Civil Pública é a vertente que certamente representaria higidamente a vontade maciça da população brasileira e, portanto, legitimaria politicamente a opção dos representantes eleitos pela população que em duas oportunidades através de quórum qualificado de Lei Complementar (LACP e LCF 132/09) elencaram a Defensoria Pública como instituição legitimada a substituir processualmente a coletividade na busca da resolução dos conflitos pertinentes por intermédio da Ação Civil Pública, inobstante a já citada EC 80/2014.

A máxima efetividade constitucional estimula e exige uma constante fiscalização acerca do atendimento e efetivação dos direitos fundamentais, seja pelos poderes públicos, seja pela iniciativa privada, nesta seara, quanto mais legitimados houver: melhor, já que o controle pela observância aos direitos fundamentais por toda a sociedade é uma árdua tarefa que se revela muito extremada para uma instituição só.

A efetivação dos direitos fundamentais de forma coletiva se revela mais consentânea à Ação Civil Pública, porquanto, restringir a legitimação para esta modalidade de instrumento jurídico vai de encontro ao princípio constitucional do acesso à justiça.

É inegável a importância da Defensoria Pública para a defesa do Estado Democrático e Social de Direito através da efetivação dos direitos fundamentais, dentre eles os interesses metaindividuais, sendo que há no país vários exemplos de soluções devidas à atuação desta Instituição em prol da tutela coletiva.

Pari passu, pensamos que a Defensoria Pública na atual conjuntura do Estado Democrático e Social de Direito se insere como tutora dos direitos das pessoas hipossuficientes, que são a maioria da sociedade, almejando a ampliação do acesso à justiça, aliás, a imensa maioria dos usuários do Sistema de Saúde Público tem perfil hipossuficiente.

Hodiernamente a atuação da Defensoria Pública se apropria de um escopo de implementação e proteção dos direitos fundamentais de todas as dimensões ou gerações de direitos. Por conseguinte, a atuação clássica da Defensoria Pública se circunscrevia inicialmente à tutela dos chamados direitos de primeira dimensão, equivale dizer: os ditos direitos liberais, tal como na defesa individual de alguém como ocorre no processo crime; evolutivamente, houve o atendimento dos direitos de segunda dimensão, isto é, os sociais, exemplificativamente com a adoção de medidas extrajudiciais e judiciais almejando obter tratamentos de saúde cirúrgicos e medicamentosos, vagas em hospitais, em escolas e creches e, por fim, a Defensoria Pública 
ISSN 1981-3694

(DOI): $10.5902 / 1981369429661$

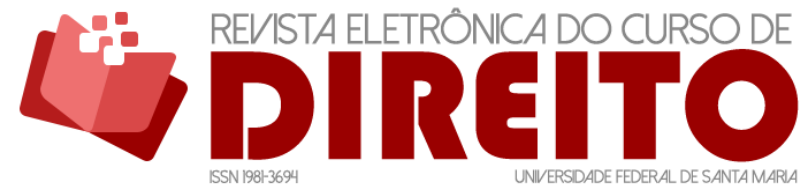

LEGITIMIDADE DA DEFENSORIA PÚBLICA PARA PROMOVER AÇÃO CIVIL PÚBLICA POR IMPROBIDADE ADMINISTRATIVA DECORRENTE DA OMISSÃO DE POLÍTICAS DE SAÚDE

abarcou também a tutela dos direitos fundamentais de terceira dimensão, tendo como cerne a solidariedade, onde se inserem os direitos metaindividuais ${ }^{(4)}$.

Antes de adentrar à natureza jurídica propriamente dita da legitimação da Defensoria Pública para a tutela coletiva, impende referir que a Legitimação Conglobante se trata de uma legitimação extraordinária decorrente de todo o ordenamento jurídico interpretado de forma global.

A legitimidade extraordinária já era admitida mesmo quando não prevista expressamente no texto legal, mas desde que o sistema não a vedasse, ou seja, o vocábulo Lei inserto no artigo $6^{\circ}$ do anterior Código de Processo Civil de 1973 já era entendido como ordenamento ou sistema jurídico pela doutrina, nesse sentido se posicionava Barbosa Moreira ${ }^{(5)}$, terminologia que foi textualmente corrigida pelo Novo Código de Processo Civil em seu artigo 18.

Tal visão sistêmica só é possível porque o sistema brasileiro não prevê a obrigatoriedade de disposição expressa acerca da substituição processual ${ }^{(6)}$.

A teoria da legitimação para a tutela coletiva se reparte em três espécies, quais sejam: a) legitimação extraordinária através de substituição processual; b) legitimação ordinária das “formações sociais” e c) legitimação autônoma para condução do processo.

$\mathrm{Na}$ tutela coletiva, a legitimação extraordinária seria o gênero da qual derivam as duas espécies: substituição processual e legitimação autônoma para condução do processo. Enquanto na legitimação ordinária se identifica o autor da demanda com o titular do direito material, na legitimação extraordinária, o titular do direito material é diverso do autor da ação, ou seja, a defesa do direito em juízo será feita não pelo titular do direito, mas por terceiro em nome próprio.

Obviamente, não se aplicando a legitimação ordinária para ações civis públicas propostas pela Defensoria Pública, esta - enquanto autora da demanda - não seria evidentemente titular do direito material; e também não sendo o caso de legitimação ordinária das "formações sociais", que consiste na possibilidade de os legitimados como titulares do próprio direito material agirem exclusivamente representando os objetivos institucionais em defesa do grupo

\footnotetext{
${ }^{4}$ Cf. FENSTERSEIFER, Tiago. Defensoria Pública, Acesso à Justiça e Justiça Ambiental. BENJAMIN, Antônio Herman; FIGUEIREDO, Guilherme José Purvin de (coord.). Direito Ambiental e as Funções Essenciais à Justiça. São Paulo: Revista dos Tribunais, 2011, p. 118.

${ }^{5}$ Cf. MOREIRA, José Carlos Barbosa. A ação popular do direito brasileiro como instrumento de tutela jurisdicional dos chamados interesses difusos. MOREIRA, José Carlos Barbosa. Temas de Direito Processual Civil. São Paulo: Saraiva, 1977, p. 111.

${ }^{6} \mathrm{Cf}$. ZANETI JR., Hermes. A legitimação conglobante nas ações coletivas: a substituição processual decorrente do ordenamento jurídico. Videre, Dourados, MS, ano 2, n. 3, p. 101-116, jan./jun.2010, passim.
} 
ISSN 1981-3694

(DOI): $10.5902 / 1981369429661$

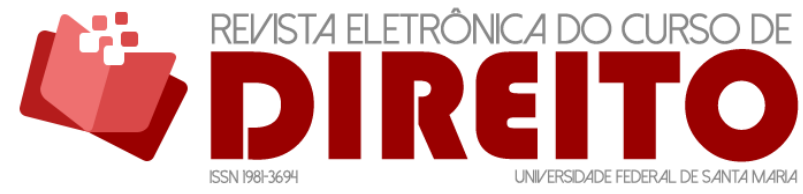

LEGITIMIDADE DA DEFENSORIA PÚBLICA PARA PROMOVER AÇÃO CIVIL PÚBLICA POR IMPROBIDADE ADMINISTRATIVA DECORRENTE DA OMISSÃO DE POLÍTICAS DE SAÚDE

MARCELO LAMY FLÁVIO ANTONIO DE OLIVEIRA

representado; outrossim, em nosso sentir, não sendo o caso de legitimação autônoma para a condução do processo, porquanto nesta hipótese o seu fundamento basilar se assentaria em autorização concedida pelo direito objetivo ao legitimado, resta a acepção de somente se admitir para a Defensoria interpretar a tal legitimação autônoma para a condução do processo com uma concepção consistente em um juízo de legitimidade conglobante do ordenamento jurídico, haja vista que na conjectura de se examinar cada legislação esparsa acerca da legitimidade da Defensoria Pública para o ajuizamento de Ações Civis Públicas, certamente se constataria equivocadamente que determinados direitos só poderiam ser tutelados por outros legitimados que não a Defensoria Pública, razão pela qual a legitimidade extraordinária conglobante seria a mais adequada para a representação que ocorre em prol da tutela coletiva instrumentalizada pela Defensoria Pública.

Logo, a legitimidade autônoma para a condução do processo por exigir que uma lei legitime determinada entidade ou órgão para a defesa da tutela coletiva somente seria compatível se olhada sob uma ótica conglobante, já que a exegese que deveria ser feita então sobre o significado da palavra lei, deveria ser o de ordenamento jurídico, isto é, de sistema jurídico.

Malgrado, a acepção supracitada, é imperioso registrar que, no ponto, há doutrina respeitada sobre o assunto entendendo que a legitimação para a Ação Civil Pública se trata de legitimação autônoma para a condução do processo:

A dicotomia clássica legitimação ordinária-extraordinária só tem cabimento para a explicação de fenômenos envolvendo direito individual. Quando a lei legitima alguma entidade a defender direito não individual (coletivo ou difuso), o legitimado não estará defendendo direito alheio em nome próprio, porque não se pode identificar o titular do direito. Não poderia ser admitida ação judicial proposta pelos 'prejudicados pela poluição', pelos 'consumidores de energia elétrica', enquanto classe ou grupo de pessoas. A legitimidade para a defesa dos direitos difuso e coletivos em juízo não é extraordinária (substituição processual), mas sim, legitimação autônoma para a condução do processo (selbständigeProzebführungsbefgnis): a lei elegeu alguém para a defesa de direitos porque seus titulares não podem individualmente fazê-lo. ${ }^{(7)}$

É hialino que em relação à tutela coletiva o ordenamento jurídico almeja uma legitimação para agir desvinculada da titularidade do direito. Contudo, a teoria da legitimação autônoma para a condução do processo visa primordialmente rechaçar a substituição processual autônoma de determinados legitimados em prol da tutela coletiva.

${ }^{7}$ NERY JR., Nelson. Código de Processo Civil Comentado. 5 ed. São Paulo: Revista dos Tribunais, 2001, p. 1866. 
A respeito da aplicabilidade da teoria da legitimação autônoma para a condução do processo, entende a doutrina:

\begin{abstract}
Portanto, por sua vez, também inadequado demonstra-se o instituto do direito de conduzir o processo (Prozebführungsbefgnis). A legitimação autônoma (direito de conduzir o processo) é uma busca alternativa ao intrincado e muitas vezes fugidio à lógica forma instituto da substituição processual, resguardadas as diferenças entre os sistemas, é compreensível dentro da chamada legitimação extraordinária por substituição autônoma exclusiva, já tradicionalmente aceita em nosso ordenamento. Assim, o autor é substituto processual, agindo sem necessidade de autorização, em nome do direito subjetivo de outrem e os próprios titulares individuais não podem fazer valer diretamente seus direitos subjetivos coletivos. ${ }^{(8)}$
\end{abstract}

Deveras, se a legitimação autônoma para a condução do processo quer significar uma autorização do ordenamento normativo para que os legitimados substituam os detentores do direito metaindividual em juízo, não há dissenso em relação à legitimação extraordinária conglobante, já que esta significa a substituição do detentor do direito material pelo legitimado que defenderá este direito em juízo. Contudo, se a legitimação autônoma para a condução do processo for considerada como decorrente de uma autorização procedida por lei em sentido estrito, ficará aquém do alcance do princípio da máxima efetividade dos direitos fundamentais, e portanto, restrita no sistema, a partir de um viés reducionista.

Alguns ainda sustentam a teoria da legitimidade adequada, que justificaria uma representação adequada e autorizada dos interesses transindividuais em juízo ${ }^{(9)}$.

Ademais, questiona-se no processo coletivo a ausência de tutela dos direitos metaindividuais quando o Poder Judiciário deixa de se pronunciar sobre as questões de fundo por rejeitar a legitimidade do autor da demanda, o que, por assim dizer, inviabilizaria o reconhecimento dos direitos metaindividuais, além de violar o princípio da instrumentalidade do processo e um princípio específico do direito processual coletivo que é o princípio do interesse jurisdicional no conhecimento do mérito no processo coletivo, concluindo-se que as regras de legitimação aplicadas no direito individual não servem totalmente ao direito coletivo ${ }^{(10)}$.

\footnotetext{
${ }^{8}$ ZANETI JR., Hermes. A legitimação conglobante nas ações coletivas: a substituição processual decorrente do ordenamento jurídico. Videre, Dourados, MS, ano 2, n. 3, p. 101-116, jan./jun.2010, p. 111-112.

${ }^{9}$ Cf. LEONEL, Ricardo de Barros. Manual do Processo Coletivo. São Paulo: Revista dos Tribunais, 2002, p. 158.

${ }^{10}$ Cf. ALMEIDA, Gregório Assagra de. Direito Processual Coletivo Brasileiro. São Paulo: Saraiva, 2003, p. 572.
} 
ISSN 1981-3694

(DOI): $10.5902 / 1981369429661$

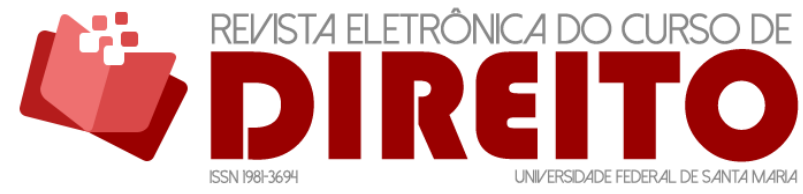

LEGITIMIDADE DA DEFENSORIA PÚBLICA PARA PROMOVER AÇÃO CIVIL PÚBLICA POR IMPROBIDADE ADMINISTRATIVA DECORRENTE DA OMISSÃO DE POLÍTICAS DE SAÚDE

Perante esta acepção instrumentalista, o sistema processual deveria ser aberto ao maior número de pessoas, haja vista que o sistema processual deveria adotar técnicas capazes de dotar o processo de maior carga de utilidade social e política.

Neste ínterim, as regras de legitimação aplicadas no direito individual não servem totalmente ao direito coletivo.

\section{A OMISSÃO NA IMPLEMENTAÇÃO DA SAÚDE PÚBLICA COMO ATO PASSÍVEL DE RESPONSABILIZAÇÃO POR IMPROBIDADE ADMINISTRATIVA}

É latente a possibilidade do exercício de controle e responsabilidade pessoal dos agentes públicos que através de sua inércia causem consequência danosa ao direito fundamental à saúde face ao dever de boa gestão, seja mediante o dever jurídico de agir desviado através de adoção de finalidade incompatível com a promessa de atuação ostentada no planejamento orçamentário sem a adequada e válida motivação, seja através de desídia à atenção ao basilar direito de acesso às ações e tratamentos de saúde, podendo a resposta a tais comportamentos culminar com a caracterização de improbidade administrativa, a qual poderia incutir - pela teoria do desestímulo - às pessoas dos gestores, uma maior responsabilidade na efetivação do direito fundamental à saúde.

Criado o Sistema Único de Saúde pela Constituição da República e organizado pela Lei nº 8.080/90, estabelecendo que qualquer pessoa física que utilize, gerencie, administre, aplique ou que perceba a título de contraprestação de serviços, recursos financeiros da União alocados ao SUS, sujeita-se a mesma à responsabilização mediante a comprovação de malversação por desvio de finalidade ou aplicação irregular dos recursos ou omissão no dever de execução da legislação relativa ao Sistema Único de Saúde - SUS, evidenciando-se como salutar o mecanismo de responsabilização pessoal do agente por improbidade administrativa por desídia no dever jurídico de boa gestão e observância aos princípios da continuidade do serviço público e eficiência.

O Estado, na conjuntura atual, optou por adotar um regime jurídico-privado de prestação de serviços públicos na área da Saúde como autorizava o artigo 197 da Constituição da República, cuja regulamentação se deu pelo advento da Lei das Organizações Sociais (Lei 9.637/98) que teve sua constitucionalidade ratificada pelo Plenário do Supremo Tribunal Federal na ADI 1.923/DF, sendo que neste regime a Administração Pública poderá celebrar contratos de gestão através de um absoluto juízo de necessidade ao talante do Administrador, mediante 
ISSN 1981-3694

(DOI): $10.5902 / 1981369429661$

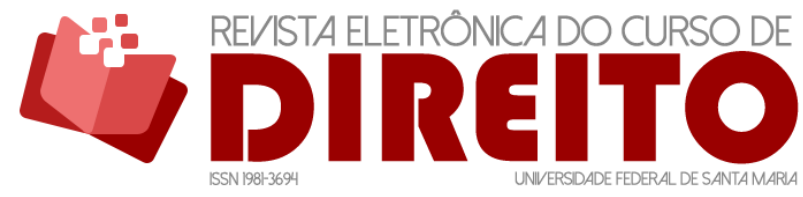

LEGITIMIDADE DA DEFENSORIA PÚBLICA PARA PROMOVER AÇÃO CIVIL PÚBLICA POR IMPROBIDADE ADMINISTRATIVA DECORRENTE DA OMISSÃO DE POLÍTICAS DE SAÚDE

sistemática aleatória de classificações de organizações que serão tituladas de "sociais", cujo subjetivismo evidente deveria implicar em maior preocupação no controle de tais contratações com o respectivo acompanhamento permanente, eis que embora tais contratações tenham de observar os princípios da legalidade, impessoalidade, moralidade, publicidade e economicidade, em seu artigo 16,§ 10, tal diploma legal, prevê a responsabilidade dos dirigentes da organização social, individual e solidariamente pelos danos ou prejuízos decorrentes de sua ação ou omissão.

As condutas negativas do gestor de saúde, o qual, injustificadamente, deixar de honrar determinações do ordenamento jurídico, de cumprir contratos firmados com os demais entes federados, de efetivamente executar os planos de saúde aprovados ou ainda descumprir determinadas metas pactuadas, salvo se comprovar justificada e abalizadamente considerável redução na arrecadação orçamentária, caracterizariam violação ao artigo 11 da LACP.

A discricionariedade como rotineira alegação de empeço para a efetivação dos direitos fundamentais não pode servir de justificação para o retardamento nem para a omissão da atuação prestacional do Estado no dever de atendimento às ações de Saúde.

Consubstancia-se a discricionariedade em mera margem variável de liberdade conferida ao agente público para a execução do ato administrativo, mas exclusivamente visando a melhor atender ao interesse coletivo. Portanto, a discricionariedade se trata de uma excepcionalidade justificada apenas pelo interesse coletivo.

Mesmo na doutrina tradicional, ainda que discricionários, os atos administrativos são também vinculados porque jungidos à sua motivação e finalidade, eis que esta deve estar prevista no ordenamento jurídico.

Já, sob uma nova perspectiva, Binenbojm ${ }^{(11)}$ prega o abandono à dicotomia entre atos administrativos vinculados e discricionários, até mesmo porque atos discricionários não podem importar em perpétua inércia do poder público na implementação de políticas preventivas e repressivas, de molde a assegurar a concretização de direitos difusos, coletivos e individuais homogêneos garantidos pela Constituição Federal. Para ele, a discricionariedade deixa de ser um espaço de livre escolha do administrador para se convolar em um resíduo de legitimidade a ser preenchido por procedimentos técnicos e jurídicos prescritos pela Constituição e pela lei com vistas à otimização do grau de legitimidade da decisão administrativa, buscando o incremento da incidência direta dos princípios constitucionais sobre a atividade administrativa e a entrada no Brasil da teoria dos conceitos jurídicos indeterminados.

${ }^{11}$ Cf. BINENBOJM, Gustavo. Uma Teoria de Direito Administrativo: direitos fundamentais, democracia e constitucionalização. 2. ed. Rio de Janeiro: Renovar, 2008, passim. 
ISSN 1981-3694

(DOI): $10.5902 / 1981369429661$

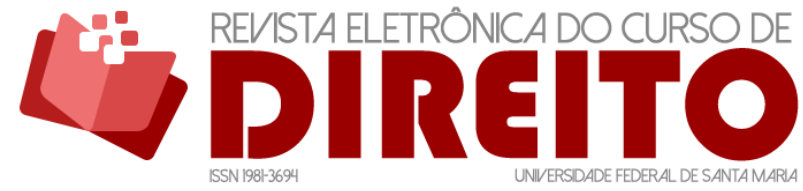

LEGITIMIDADE DA DEFENSORIA PÚBLICA PARA PROMOVER AÇÃO CIVIL PÚBLICA POR IMPROBIDADE ADMINISTRATIVA DECORRENTE DA OMISSÃO DE POLÍTICAS DE SAÚDE

Enfim, não há discricionariedade em qualquer grau que seja que possa servir de autorização ao gestor de saúde para que omita ou retarde ato de ofício, contra expresso mandamento ou entendimento constante do ordenamento jurídico, eis que o escudo da discricionariedade não pode blindar o gestor público ao nível de pretender autorizar omissões administrativas travestidas de rejeição das finalidades administrativas, já que significaria negação ao atendimento do próprio interesse coletivo, para cujo atendimento o Estado foi criado.

A amplitude do alcance da Lei de Improbidade Administrativa (art. 11) não pode ser afastada pela alegação de conveniência e discricionariedade do agente público na gestão da Saúde, eis que tem ele o dever jurídico de agir conforme os princípios constitucionais garantidores de boa gestão, moralidade, eficiência e máxima efetividade dos direitos fundamentais, além de outros. Portanto, evidenciada a inércia e o elemento subjetivo subsumido na omissão do dever jurídico de agir, prescindindo-se tratar-se de discricionário ou vinculado o ato omitido ou retardado, haverá possibilidade de responsabilização pessoal se o interesse público foi indevidamente substituído por qualquer outro.

É curial notar que a garantia fundamental do direito à saúde e em última análise à preservação da vida humana assegurados constitucionalmente impõe ao Administrador Público a execução de políticas públicas com viés vinculativo proporcional à previsão de despesas alocadas como prioritárias e autorizadas pela Lei Orçamentária. Porém, a realidade cotidiana traduz sensação de desproporcionalidade entre a arrecadação fiscal e a aplicação de tais recursos nas prioritárias políticas públicas concernentes às ações de saúde, impondo a atuação do Poder Judiciário no escopo de assegurar o almejado direito à saúde.

\section{A SITUAÇÃO EMPÍRICA DA LEGITIMAÇÃO}

No afã de trazer à percepção o enfoque pragmático da exegese da legitimação, é possível afirmar: apesar de a Lei $n^{\circ}$ 8.429/92 prever que a ação principal de improbidade deva ser proposta pelo Ministério Público (art. 17), o substrato teórico constitucional e processual anteriormente explicitado exige inferir a possibilidade de a Defensoria Pública ajuizar a Ação Civil de Improbidade Administrativa quando a mesma possuir elementos de convicção suficientes para comprovar o teor dos respectivos pedidos.

Assim, adotando a classificação que defende ser a ação de improbidade uma espécie de ação civil pública, agora há de se considerar a Lei 13.004/14 que incluiu expressamente na Lei 
ISSN 1981-3694

(DOI): $10.5902 / 1981369429661$

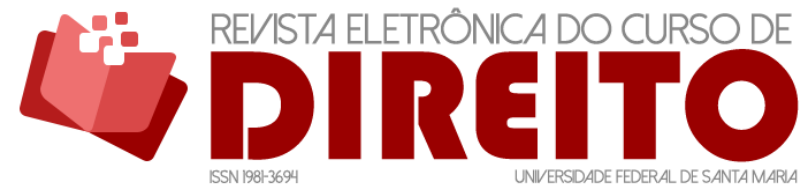

LEGITIMIDADE DA DEFENSORIA PÚBLICA PARA PROMOVER AÇÃO CIVIL PÚBLICA POR IMPROBIDADE ADMINISTRATIVA DECORRENTE DA OMISSÃO DE POLÍTICAS DE SAÚDE

da Ação Civil Pública, Lei $7.347 / 85$, o inciso VIII ao artigo $1^{\circ}$, que possibilita expressamente a tutela do patrimônio público e social.

Pois bem, o artigo $1^{\circ}$ "caput" da Lei 7.347/85, dispõe seguirem primordialmente o procedimento estipulado nesta Lei as ações judiciais que versarem sobre responsabilidade por danos morais e patrimoniais causados em detrimento dos bens jurídicos que exemplificativamente elenca em seus incisos, incluída cominação de fazer ou não fazer, como prevê seu artigo $3^{\circ}$, e subsidiariamente respeitando o Código de Processo Civil.

Logo, de forma hialina se verifica que a Lei 7.347/85 é uma Lei eminentemente processual, e engloba a tutela processual do patrimônio público e social.

Portanto, pelo cotejo acima procedido e diante positivação expressa na Lei de Ação Civil Pública (Lei 7.347/85) da tutela processual do patrimônio público e social, em razão da inclusão do inciso VIII ao artigo $1^{\circ}$ pela Lei $13.004 / 14$, e também pela expressa previsão no artigo $5^{\circ}$, inciso II deste mesmo diploma da legitimação irrestrita da Defensoria Pública, infere-se que não há como exsurgir um raciocínio diverso daquele que contempla a legitimidade irrestrita da Defensoria Pública exercer a tutela do patrimônio público e da moralidade e probidade administrativas através da Ação Civil Pública.

Constata-se da pesquisa empreendida que apesar de não haver antes do advento da Lei 13.004/2014 que alterou a LACP nenhum aresto específico sobre a tutela da probidade administrativa pela Defensoria Pública no âmbito da jurisprudência dos Tribunais de Superposição, é certo que na ADI 3.943 (julgada em 07/05/2015) - ou seja, posteriormente à própria edição da supracitada Lei 13.004/2014 -, o STF reconheceu a constitucionalidade da inserção da Defensoria Pública no rol dos Legitimados da Lei da Ação Civil Pública irrestritamente, sendo assim, com a nova previsão expressa no inciso VIII da Lei 7.347/85 da possibilidade de tutela processual do patrimônio público e social por meio de Ação Civil Pública, é forçoso o reconhecimento em controle concentrado de constitucionalidade com eficácia erga omnes pelo Pretório Excelso da possibilidade de tutela da probidade administrativa por meio de Ação Civil Pública através da Defensoria Pública, cuja observância é obrigatória por juízes e Tribunais nos termos do artigo 927, inciso I do CPC. Sic:

EMENTA: AÇÃO DIRETA DE INCONSTITUCIONALIDADE. LEGITIMIDADE ATIVA DA DEFENSORIA PÚBLICA PARA AJUIZAR AÇÃO CIVIL PÚBLICA (ART. 5², INC. II, DA LEI N. 7.347/1985, ALTERADO PELO ART. 2० DA LEI N. 11.448/2007). TUTELA DE INTERESSES TRANSINDIVIDUAIS (COLETIVOS STRITO SENSU E DIFUSOS) E INDIVIDUAIS HOMOGÊNEOS. DEFENSORIA PÚBLICA: INSTITUIÇÃO ESSENCIAL À FUNÇÃO JURISDICIONAL. ACESSO À JUSTIÇA. NECESSITADO: DEFINIÇÃO SEGUNDO PRINCÍPIOS 
LEGITIMIDADE DA DEFENSORIA PÚBLICA PARA PROMOVER AÇ̃̃o CIVIL PÚBLICA POR IMPROBIDADE ADMINISTRATIVA DECORRENTE DA OMISSÃO DE POLÍTICAS DE SAÚDE

HERMENÊUTICOS GARANTIDORES DA FORÇA NORMATIVA DA CONSTITUIÇÃO E DA MÁXIMA EFETIVIDADE DAS NORMAS CONSTITUCIONAIS: ART. 5', INCS. XXXV, LXXIV, LXXVIII, DA CONSTITUIÇÃO DA REPÚBLICA. INEXISTÊNCIA DE NORMA DE EXCLUSIVIDAD DO MINISTÉRIO PÚBLICO PARA AJUIZAMENTO DE AÇÃO CIVIL PÚBLICA. AUSÊNCIA DE PREJUIIZO INSTITUCIONAL DO MINISTÉRIO PÚBLICO PELO RECONHECIMENTO DA LEGITIMIDADE DA DEFENSORIA PÚBLICA. AÇÃO JULGADA IMPROCEDENTE. (12)

Neste sentido, posicionou-se o Egrégio Tribunal de Justiça do Rio Grande do Sul em Agravo de Instrumento interposto pelo Ministério Público em face da Defensoria Pública, cuja ementa segue transcrita abaixo. A decisão é da relatoria do Des. Carlos Roberto Lofego Caníbal da $1^{\text {a }}$ Câmara Cível proferida nos autos $n^{\circ} 70034602201$, mencionando ela que é manifesta a legitimidade da Defensoria Pública para a propositura de Ação Civil Pública não apenas em defesa dos necessitados em atenção às suas finalidades institucionais, como também na tutela de todo e qualquer direito difuso, coletivo ou individual homogêneo:

AGRAVO DE INSTRUMENTO. CONSTITUCIONAL E ADMINISTRATIVO. AÇÃO CIVIL PÚBLICA POR ATO DE IMPROBIDADE ADMINISTRATIVA. LEGITIMIDADE DA DEFENSORIA PÚBLICA. A conjunção da Constituição Federal com as leis $n^{\circ}$ 7.347/85 (art. $5^{\circ}$, II, com a redação que the deu a Lei $n^{\circ} 11.448 / 07$ ), Lei Orgânica da Defensoria Pública (artigos $1^{\circ}, 3^{\circ}$ e $4^{\circ}$, com a redação que the deu a LC $n^{\circ}$ 132/09) não deixa dúvidas acerca da legitimidade da Defensoria Pública para a propositura de ação civil pública não apenas na defesa dos necessitados, em atenção às suas finalidades institucionais, mas também na tutela de todo e qualquer direito difuso, coletivo ou individual homogêneo, na forma da lei. É manifesta a legitimidade da Defensoria Pública para as ações coletivas que visem garantir, modo integral e universal, a tutela de direitos difusos, coletivos ou individuais homogêneos, e garantir, acima de tudo, o postulado da dignidade da pessoa humana, que é um dos fundamentos do nosso Estado Democrático de Direito. Hipótese concreta em que a Ação Civil Pública ajuizada pela Defensoria Pública visa apurar supostos atos de improbidade administrativa cometidos por administradores da APAE - Associação de Pais e Amigos dos Excepcionais. Legitimidade ativa reconhecida. Decisão a quo que indeferiu pedido de extinção da lide sem resolução de mérito que vai confirmada. RECURSO DESPROVIDO. VOTO VENCIDO. ${ }^{(13)}$

É curial notar que a Lei Complementar Federal n 132/2009 que alterou substancialmente a Lei Orgânica Nacional da Defensoria Pública (Lei Complementar Federal n 80/94), em seu

\footnotetext{
${ }^{12}$ BRASIL. Supremo Tribunal Federal, Tribunal Pleno. Acórdão de ADI n. 3.943. Relatora: Min. CÁRMEN LÚCIA. Data de Julgamento: 07/05/2015. Publicação: Diário da Justiça do dia 05/08/2015.

${ }_{13}$ RIO GRANDE DO SUL. Tribunal de Justiça, Primeira Câmara Cível. Acórdão do Agravo de Instrumento n. 70034602201. Relator: Des. Carlos Roberto Lofego Canibal. Data de Julgamento: 19/05/2010. Publicação: Diário da Justiça do dia 02/07/2010.
} 
ISSN 1981-3694

(DOI): $10.5902 / 1981369429661$

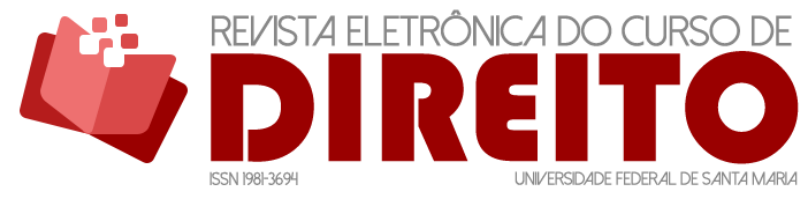

LEGITIMIDADE DA DEFENSORIA PÚBLICA PARA PROMOVER AÇÃO CIVIL PÚBLICA POR IMPROBIDADE ADMINISTRATIVA DECORRENTE DA OMISSÃO DE POLÍTICAS DE SAÚDE

artigo $4^{\circ}$ estipulou como funções institucionais da Defensoria a promoção de ação civil pública $e$ de todas as espécies de ações capazes de propiciar a adequada tutela dos direitos difusos, coletivos ou individuais homogêneos quando o resultado da demanda puder beneficiar grupo de pessoas hipossuficientes, bem como a promoção da mais ampla defesa dos direitos fundamentais dos necessitados, abrangendo seus direitos individuais, coletivos, sociais, econômicos, culturais e ambientais, sendo para tanto admissíveis todas as espécies de ações capazes de propiciar sua adequada e efetiva tutela, e no caso, o direito à saúde trata-se de um direito social, além de fundamental.

Com efeito, a análise deste dispositivo permite facilmente constatar que a Ação Civil Pública pode ser proposta pela Defensoria Pública relativamente a promoção da responsabilização por improbidade administrativa decorrente de omissão injustificada na promoção da saúde, assim como relativamente a qualquer tema, já que é inegável que sempre haverá - em um juízo perfunctório - uma possibilidade de efeitos reflexos benéficos ao menos a um grupo de hipossuficientes.

A tutela coletiva abarca os chamados direitos essencialmente coletivos, que compreendem os difusos e os coletivos propriamente ditos previstos nos incisos I e II do parágrafo único do artigo 81 do Código de Defesa do Consumidor, bem como os direitos de natureza coletiva pela forma como são tutelados, consubstanciando-se nos direitos individuais homogêneos, com previsão no inciso III do supracitado diploma legal.

A tutela dos interesses difusos apenas coletivamente pode se efetivar em razão da indivisibilidade do seu objeto, o que impossibilita mensurar eventual porção de direito cabível a cada interessado.

O viés da solidariedade é o alicerce da legitimidade da Defensoria Pública na atuação coletiva, pois, o princípio da solidariedade está positivado como objetivo fundamental da República em sua respectiva Constituição (art. $3^{\circ}$ ), revelando a Defensoria Pública como instituição estatal apta a servir de instrumento para tentar - de forma irrestrita - promover a redução da pobreza e da marginalização, bem como a redução das desigualdades sociais e regionais e em última instância, a promoção do bem de todos, no que o direito à sadia qualidade de vida e à saúde estão inseridos, em suma, essencialmente visando promover a dignidade do ser humano, já que o princípio que protege a dignidade da pessoa humana é a pedra fundamental e objeto maior da instituição.

A teoria da legitimação extraordinária conglobante para a tutela coletiva ainda se justifica considerando que o artigo 82 da Lei 8.072/90 (Código de Defesa do Consumidor), não 
ISSN 1981-3694

(DOI): $10.5902 / 1981369429661$

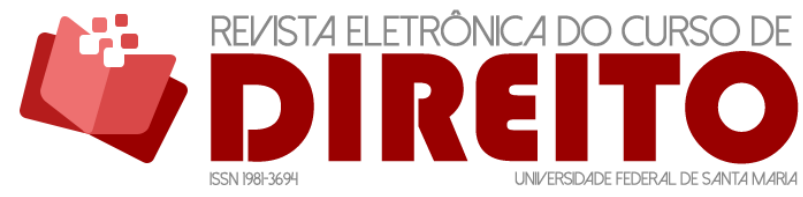

LEGITIMIDADE DA DEFENSORIA PÚBLICA PARA PROMOVER AÇÃO CIVIL PÚBLICA POR IMPROBIDADE ADMINISTRATIVA DECORRENTE DA OMISSÃO DE POLÍTICAS DE SAÚDE

prevê expressamente a Defensoria Pública como legitimada para a defesa coletiva dos direitos dos consumidores, embora fosse possível incluí-la no inciso III do referido artigo, já que a Defensoria Pública é um órgão da Administração Pública sem personalidade jurídica e segundo sua Lei Orgânica Nacional (Lei Complementar $n^{\circ}$ 80/94 e 132/09), destinada à defesa dos interesses e direitos decorrentes da relação de consumo.

A melhor orientação jurisprudencial admite a legitimidade da Defensoria Pública para as Ações Coletivas sem restrições, inclusive acerca de qualquer temática, vale dizer, abrangendo a improbidade administrativa.

\section{A NECESSIDADE COMO JUSTIFICAÇÃO DA LEGITIMAÇÃO CONGLOBANTE}

É certo que o artigo 134 da Constituição Federal - aliás, o único que trata da Defensoria Pública enquanto carreira em status constitucional -, prevê que o exercício das atribuições dos membros desta carreira seja em prol dos necessitados. A este respeito convém refletir: qual o conceito de necessitados falando-se em tutela coletiva, excetuada a pertinente a direitos individuais homogêneos?

Antes de se posicionar propriamente sobre a concepção de quem se amolda na categoria necessitado em uma ação coletiva, faz-se mister vislumbrar que no Brasil, embora o governo federal classifique classe média como toda família que tem renda familiar mensal entre R\$1.064 e R\$ 4.561 e em que pese a FGV - Fundação Getúlio Vargas classificar a classe C como a representada por famílias com renda entre $\mathrm{R} \$ 1.734$ e $\mathrm{R} \$ \mathbf{7 . 4 7 5}$, cujos modelos são criticados pela amplitude demasiada dentro de uma mesma classe social, revelando não homogeneidade, segundo dados obtidos perante o GEU - Grupo de Estudos Urbanos ${ }^{(14)}$, que propõe o modelo de classes sociais estratificadas em A, B1 e B2, C1, C2 e C3 e D e E, é importante notar que no atendimento individual perante as Defensorias Públicas do país, o critério de atendimento gravita em torno de renda familiar entre três a cinco salários mínimos, podendo se flexibilizar um pouco este critério mediante a comprovação de dívidas e restrição de bens por passivo fundado em obrigações não supérfluas.

Ocorre que na concepção do GEU - Grupo de Estudos Urbanos, as classes D e E, as quais compreendem $37,9 \%$ da população, possuem renda de até $R \$ 1.627,00$ e a classe $C 3$, que

${ }^{14}$ Cf. GRUPO DE ESTUDOS URBANOS (GEU). Fim da polêmica sobre as classes sociais. Disponibilizada anteriormente em <http://www.geu.com.br/news/fim-da-polemica-sobre-as-classes-sociais> Acessada em: 14-08-2013. Reproduzida em http://www.gurumarket.com.br/fim-da-polemica-sobre-as-classessociais/ Acesso em 03/01/2017. 
ISSN 1981-3694

(DOI): $10.5902 / 1981369429661$

LEGITIMIDADE DA DEFENSORIA PÚBLICA PARA PROMOVER AÇÃO CIVIL PÚBLICA POR IMPROBIDADE ADMINISTRATIVA DECORRENTE DA OMISSÃO DE POLÍTICAS DE SAÚDE

compreende $29,1 \%$ da população, aufere renda entre $\mathrm{R} \$ 1.628,00$ a $\mathrm{R} \$ 2.441,00$, enquanto que a classe C2, que atinge $11,7 \%$ da população, galga renda entre $R \$ 2.442,00$ a $R \$ 4.882,00$. Nesta linha de raciocínio, somando-se as classes D e E e C3, teremos um contingente populacional nacional de necessitados da ordem de mais de $69 \%$ da população, sem considerar provável parte do contingente da classe C2 que também fazem jus à assistência judiciária gratuita e integral, quando então o contingente de necessitados passará de $70 \%$ da população que teriam direito à assistência judiciária gratuita e integral outorgada pelo Estado através da Defensoria Pública.

Obviamente, isto significa que mais de $70 \%$ da população brasileira tem perfil para utilização da Saúde Pública, logicamente a defesa de tal coletividade visando a improbidade administrativa do gestor da saúde por omissão nefasta na promoção da política de saúde, indubitavelmente suprimiria eventual crítica à legitimidade da Defensoria Pública sobre o assunto.

Após esse enfoque de estimação estatística, o qual não foi possível ser evitado, é preciso compreender que a tutela coletiva, salvo a dos direitos individuais homogêneos, inevitavelmente abrangerá um contexto populacional maior de tutelados/necessitados dentro do aspecto de hipossuficiência financeira que autorizaria a representação pela Defensoria Pública em comparação com os supostamente não necessitados. Por outro viés, se mais de $70 \%$ da população se insere dentro dos critérios de hipossuficiência que seriam exigidos para uma triagem de atendimento individual, como se questionar a legitimidade conglobante da Defensoria Pública para a tutela coletiva de direitos metaindividuais que poderiam também proteger parte da sociedade que não se inseriria dentro do critério individual socioeconômico?

Os direitos difusos e coletivos devem ser tutelados para todas as presentes e futuras gerações, não devendo haver segregação por classes, afinal são objetivos fundamentais da nossa república a promoção do bem de todos, a redução das desigualdades sociais e a construção de uma sociedade solidária, de forma que a necessidade coletiva justifica a legitimidade conglobante da Defensoria Pública que teria por escopo ser mais uma instituição a agir proativamente em busca do bem-estar da população.

Malgrado o foco eminentemente jurídico deste articulado, a hipossuficiência financeira não é o único elemento autorizante da legitimidade jurídica da Defensoria Pública, a vulnerabilidade de maneira ampla também consubstancia-se em fator autorizante. 
ISSN 1981-3694

(DOI): $10.5902 / 1981369429661$

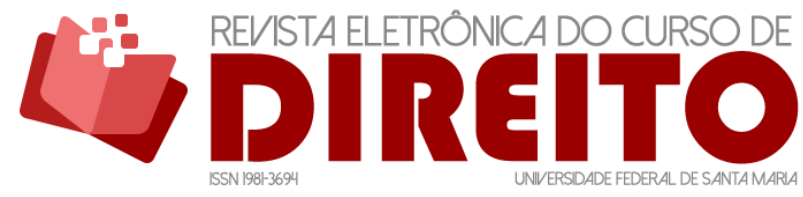

LEGITIMIDADE DA DEFENSORIA PÚBLICA PARA PROMOVER AÇÃO CIVIL PÚBLICA POR IMPROBIDADE ADMINISTRATIVA DECORRENTE DA OMISSÃO DE POLÍTICAS DE SAÚDE

Os ensinamentos de Werneck Viana e Burgos ${ }^{(15)}$, no afã de justificar e desenvolver a “mens legis inclusiva” decorrente do ordenamento jurídico, são esclarecedores.

Werneck Viana e Burgos ${ }^{(16)}$ apontam a existência de uma representação funcional do sistema de justiça extensiva da representação política, que reforça a vulnerabilidade da cidadania política. A apresentação da temática da tutela coletiva de direitos sob uma perspectiva sociológica de caráter inclusivo e de viés democrático-progressivo permite, por outro lado, uma conformação necessariamente revolucionária do direito processual coletivo.

Em sua concepção, os fatores sociais deveriam gravitar de modo isonômico nas discussões de políticas públicas, nas arenas apropriadas de debates inerentes às instituições políticas, em prol da consolidação da cidadania e do ideal do bem-comum. Contudo, na desventura de um déficit de legitimidade representativa dos segmentos populares da sociedade no âmbito político, coadunaria-se a atuação processual coletiva como um instrumento supletivo da carência representativa política desses segmentos.

Por conseguinte, a aproximação entre os aspectos político e jurídico, também insere a Defensoria Pública como instrumento de realização de justiça social e de abertura democrática processual enaltecendo o amplo acesso à Justiça.

\section{CONCLUSÃO}

Diante de todo o explanado, conclui-se que o reconhecimento da ilimitação temática por meio da legitimidade ativa conglobante - concretiza-se como hígido mecanismo interpretativo de viabilização prática da atuação plena da Defensoria Pública em prol da máxima efetivação de direitos e garantias fundamentais em juízo, mormente no que concerne ao direito à saúde, que é por excelência o fundamental dos direitos fundamentais, já que a proteção da existência do ser humano é o fator preponderante que permite a cogitação de todos os outros direitos.

Ademais, no que tange aos aspectos de fiscalização e efetivação dos direitos e garantias fundamentais que transcendem do individual ao coletivo, há verdadeira imposição dos critérios pluralistas de ampliação e inclusão (e não de restrição e exclusão), motivo pelo qual a superação da nódoa aqui abordada impõe-se como conditio sine qua non para a operacionalização coerente

\footnotetext{
${ }^{15}$ Cf. WERNECK VIANNA, Luiz; BURGOS, Marcelo. Revolução processual do direito e democracia progressiva. In: A democracia e os três poderes no Brasil. Belo Horizonte:UFMG; Rio de Janeiro: IUPERJ/FAPERJ, 2002. P. 336-491.

${ }^{16}$ Ibidem.
} 
ISSN 1981-3694

(DOI): $10.5902 / 1981369429661$

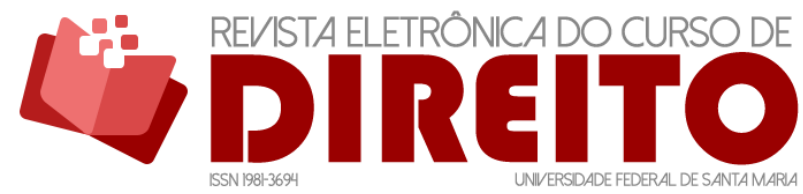

LEGITIMIDADE DA DEFENSORIA PÚBLICA PARA PROMOVER AÇÃO CIVIL PÚBLICA POR IMPROBIDADE ADMINISTRATIVA DECORRENTE DA OMISSÃO DE POLÍTICAS DE SAÚDE

do ordenamento jurídico pátrio à luz dos princípios da máxima efetividade das normas constitucionais e do acesso à justiça: vetores de racionalidade constitucional que - por sua magnitude e supremacia - jamais podem se ofuscar pela perversa exegese parcial das inferiores disposições normativas especiais.

\section{REFERÊNCIAS}

ALMEIDA, Gregório Assagra de. Direito Processual Coletivo Brasileiro. São Paulo: Saraiva, 2003.

BASTOS, Celso Seixas Ribeiro; BRITO, Carlos Ayres de. Interpretação e Aplicabilidade das Normas Constitucionais. SP: Saraiva, 1982.

BINENBOJM, Gustavo. Uma Teoria de Direito Administrativo: direitos fundamentais, democracia e constitucionalização. 2. ed. Rio de Janeiro: Renovar, 2008.

BOSON, Erik Palácio. A Defensoria Pública e a Tutela Jurisdicional da Moralidade Administrativa. 2014.103 f. Dissertação (Mestrado em Direito). Universidade de São Paulo. Faculdade de Direito. Disponível em: < http://www.teses.usp.br/teses/disponiveis/2/2134/tde06112015-142121/pt-br.php >. Acesso em: 25 jan. 2018.

BRASIL. Supremo Tribunal Federal, Tribunal Pleno. Acórdão de ADI n. 3.943. Relatora: Min. CÁRMEN LÚCIA. Data de Julgamento: 07/05/2015. Publicação: Diário da Justiça do dia 05/08/2015.

FENSTERSEIFER, Tiago. Defensoria Pública, Acesso à Justiça e Justiça Ambiental. BENJAMIN, Antônio Herman; FIGUEIREDO, Guilherme José Purvin de (coord.). Direito Ambiental e as Funções Essenciais à Justiça. São Paulo: Revista dos Tribunais, 2011.

GRUPO DE ESTUDOS URBANOS (GEU). Fim da polêmica sobre as classes sociais. Disponibilizada anteriormente em < http://www.geu.com.br/news/fim-da-polemica-sobre-as-classes-sociais $>$ Acessada em: 14-08-2013. Reproduzida em < http://www.gurumarket.com.br/fim-da-polemicasobre-as-classes-sociais > Acesso em: 03 jan. 2017.

LEONEL, Ricardo de Barros. Manual do Processo Coletivo. São Paulo: Revista dos Tribunais, 2002.

NERY JR., Nelson. Código de Processo Civil Comentado. 5. ed. São Paulo: Revista dos Tribunais, 2001. 
LEGITIMIDADE DA DEFENSORIA PÚBLICA PARA PROMOVER AÇÃO CIVIL PÚBLICA POR IMPROBIDADE ADMINISTRATIVA DECORRENTE

DA OMISSÃO DE POLÍTICAS DE SAÚDE

MOREIRA, José Carlos Barbosa. A ação popular do direito brasileiro como instrumento de tutela jurisdicional dos chamados interesses difusos. In: MOREIRA, José Carlos Barbosa. Temas de Direito Processual Civil. São Paulo: Saraiva, 1977. p. 110-123.

RIO GRANDE DO SUL. Tribunal de Justiça, Primeira Câmara Cível. Acórdão do Agravo de Instrumento n. 70034602201. Relator: Des. Carlos Roberto Lofego Canibal. Data de Julgamento: 19/05/2010. Publicação: Diário da Justiça do dia 02/07/2010.

SALDANHA, Alexandre de Moraes. Da legitimidade ativa da defensoria pública para a propositura de demandas pela prática de atos de improbidade administrativa. Revista da Defensoria Pública da União. Brasília, n. 7 (2014). Disponível em: <

http://revistadadpu.dpu.def.br/index.php/dpu/article/view/40/37 >.

WERNECK VIANNA, Luiz; BURGOS, Marcelo. Revolução processual do direito e democracia progressiva. In: A democracia e os três poderes no Brasil. Belo Horizonte:UFMG; Rio de Janeiro: IUPERJ/FAPERJ, 2002. P. 336-491.

ZANETI JR., Hermes. A legitimação conglobante nas ações coletivas: a substituição processual decorrente do ordenamento jurídico. Videre, Dourados, MS, ano 2, n. 3, p. 101-116, jan./jun.2010.

\section{COMO FAZER A REFERÊNCIA DO ARTIGO (ABNT):}

\footnotetext{
LAMY, Marcelo; OLIVEIRA, Flávio Antonio de. Legitimidade da Defensoria Pública para promover Ação Civil Pública por improbidade administrativa decorrente da omissão de políticas de saúde. Revista Eletrônica do Curso de Direito da UFSM, Santa Maria, RS, v. 13, n. 1, p. 340-369, abr. 2018. ISSN 1981-3694. Disponível em: < https: //periodicos.ufsm.br/revistadireito/article/view/29661 >. Acesso em: dia mês. ano. doi: http://dx.doi.org/10.5902/1981369429661 .
} 